\title{
Synthesis and Applications of 2,7-Carbazole-Based Conjugated Main-Chain Copolymers Containing Electron Deficient Bithiazole Units for Organic Solar Cells
}

\author{
DHANANJAYA PATRA, ${ }^{1}$ DURYOdHAN SAHU, ${ }^{1}$ HARIHARA PADHY, ${ }^{1}$ DHANANJAY KEKUDA, ${ }^{2}$ CHIH-WEI CHU, ${ }^{2,3}$ HONG-CHEU LIN ${ }^{1}$ \\ ${ }^{1}$ Department of Materials Science and Engineering, National Chiao Tung University, Hsinchu, Taiwan, Republic of China \\ ${ }^{2}$ Research Center for Applied Sciences, Academia Sinica, Taipei, Taiwan, Republic of China \\ ${ }^{3}$ Department of Photonics, National Chiao Tung University, Hsinchu, Taiwan, Republic of China
}

Received 11 July 2010; accepted 21 August 2010

DOI: $10.1002 /$ pola.24356

Published online 5 October 2010 in Wiley Online Library (wileyonlinelibrary.com).

\begin{abstract}
A series of low-band-gap (LBG) donor-accepor conjugated main-chain copolymers (P1-P4) containing planar 2,7carbazole as electron donors and bithiazole units $\left(4,4^{\prime}\right.$-dihexyl2,2'-bithiazole and 4,4'-dihexyl-5,5'-di(thiophen-2-yl)-2,2'-bithiazole) as electron acceptors were synthesized and studied for the applications in bulk heterojunction (BHJ) solar cells. The effects of electron deficient bithiazole units on the thermal, optical, electrochemical, and photovoltaic (PV) properties of these LBG copolymers were investigated. Absorption spectra revealed that polymers P1-P4 exhibited broad absorption bands in UV and visible regions from 300 to $600 \mathrm{~nm}$ with optical band gaps in the range of 1.93-1.99 eV, which overlapped with the major region of the solar emission spectrum. Moreover, carbazole-based polymers P1-P4 showed low values of the highest occupied molecular orbital (HOMO) levels, which
\end{abstract}

provided good air stability and high open circuit voltages $\left(V_{\mathrm{oc}}\right)$ in the PV applications. The BHJ PV devices were fabricated using polymers $\mathbf{P 1 - P 4}$ as electron donors and $(6,6)$-phenyl- $\mathrm{C}_{61^{-}}$ butyric acid methyl ester $\left(\mathrm{PC}_{61} \mathrm{BM}\right)$ or $(6,6)$-phenyl- $\mathrm{C}_{71}$-butyric acid methyl ester ( $\left.P C_{71} B M\right)$ as electron acceptors in different weight ratios. The PV device bearing an active layer of polymer blend $\mathrm{P} 4: \mathrm{PC}_{71} \mathrm{BM}(1: 1.5 \mathrm{w} / \mathrm{w})$ showed the best power conversion efficiency value of $1.01 \%$ with a short circuit current density $\left(J_{\mathrm{sc}}\right)$ of $4.83 \mathrm{~mA} / \mathrm{cm}^{2}$, a fill factor $(\mathrm{FF})$ of $35 \%$, and $V_{\mathrm{oc}}=$ $0.60 \mathrm{~V}$ under $100 \mathrm{~mW} / \mathrm{cm}^{2}$ of $\mathrm{AM} 1.5$ white-light illumination. (C) 2010 Wiley Periodicals, Inc. J Polym Sci Part A: Polym Chem 48: 5479-5489, 2010

KEYWORDS: bithiazole units; bulk heterojunction; copolymers; donor-acceptor
INTRODUCTION In the 21st century, to reduce carbon emissions and green house effects, solar energy is one of the "green" and "sustainable energy" sources to create better environment. Recently, organic semiconducting materials, including $\pi$-conjugated polymers ${ }^{1}$ and small molecules, ${ }^{2}$ have been used in various optical and electronic devices because of their unique advantages, such as light weight, low-cost production, and large area device fabrication by solution process. ${ }^{3}$ The highly efficient organic solar cell devices belong to the bulk heterojunction (BHJ) solar cells, in which $\pi$-conjugated polymers are used as electron donors and the fullerene derivatives, such as [6,6]-phenyl- $\mathrm{C}_{61}$-butyric acid methyl ester $\left(\mathrm{PC}_{61} \mathrm{BM}\right)$ or $[6,6]$-phenyl- $\mathrm{C}_{71}$-butyric acid methyl ester $\left(\mathrm{PC}_{71} \mathrm{BM}\right)$, as electron acceptors. After an extensive investigation on polymer solar cells (PSCs), the BHJ devices based on polymer blends (with various weight ratios and thicknesses) of poly(3-hexylthiophene) (P3HT) and $\mathrm{PC}_{61} \mathrm{BM}$ were taken as standard devices. However, the enhancements of power conversion efficiency (PCE) values in these devices are quite difficult because of low open circuit voltage $\left(V_{\text {oc }}\right)$ values $(\sim 0.6$
V) and large band gaps, which limit their net light harvesting capabilities. Hence, the utilization of newly developed lowband-gap (LBG) conjugated polymers likely to be the promising alternatives of P3HT for PSCs. Recently, PCE values up to 6.0-7.7\% were obtained by using LBG conjugated polymers in the BHJ solar cells as electron donors. ${ }^{4}$ Nevertheless, these PCEs are not sufficient for commercialization of PSCs. Therefore, promising efforts are required to develop new donoracceptor (D-A) polymer structures with higher molecular crystallinity which can result in better $\pi-\pi$ stacking, extended absorption, higher mobility, and balanced charge transport to get higher PCE values in PSCs. ${ }^{1(\mathrm{e})}$

Later, there were several reports on D-A PSCs, ${ }^{5-14}$ which harvest maximum solar spectrum ranging from visible to near infrared absorptions which appealed high short circuit current density $\left(U_{\mathrm{sc}}\right)$ values. It has been verified that $V_{\mathrm{oc}}$ is directly proportional to the difference between the highest occupied molecular orbital (HOMO) levels of donor polymers and the lowest unoccupied molecular orbital (LUMO) 
levels of acceptor PCBM derivatives (i.e., $\mathrm{PC}_{61} \mathrm{BM}$ and $\left.\mathrm{PC}_{71} \mathrm{BM}\right) .{ }^{1(\mathrm{c}, \mathrm{d}), 3}$ In BHJ solar cells, where PCBM is used as an acceptor, the ideal band gap (in order to achieve a high $V_{\mathrm{oc}}$ value) of donor polymer should be in the range of 1.2-1.9 $\mathrm{eV}$ which corresponds to a HOMO energy level between -5.8 and $-5.2 \mathrm{eV}$ and a LUMO energy level between -4.0 and $-3.8 \mathrm{eV}^{7,1(\mathrm{c}, \mathrm{d})}$ Furthermore, to facilitate efficient electron transfer from donor to acceptor, the minimum energy difference between LUMO levels of electron donor and acceptor should be ca. $0.3 \mathrm{eV}^{8,10(\mathrm{~b}, \mathrm{c})}$ Consequently, to obtain the desired molecular energy levels of the conjugated LBG polymers, electron-donating groups or electron-withdrawing groups can be substituted alternatively in the polymer backbones either to raise the HOMO energy level or to reduce the LUMO energy level. ${ }^{1(\mathrm{c}), 3}$

Conjugated polymers having D-A architectures have been extensively studied by using fused heterocyclic electron rich segments, such as carbazole, ${ }^{10}$ dibenzosilole, ${ }^{11}$ cyclopentadithiophene, ${ }^{12}$ dithienopyrrole, ${ }^{13}$ dithienosilole, ${ }^{14}$ fluorene, ${ }^{15}$ and phenothiazine ${ }^{16}$ as an electron donating building block for PSCs as well as organic field effect transistors. Owing to the easy modulations of physical properties, it has been proven that 2,7-carbazole derivatives are one of the excellent potential donor candidates for BHJ solar cells. ${ }^{10(\mathrm{~b})}$ Using 2,7carbazole-based alternating copolymer (PCDTBT) as an electron donor, Leclerc et al. achieved a PCE value of $3.6 \%{ }^{10(a)}$ Hence, with improving absorption characteristics and charge-carrier mobilities, Heeger et al. reported an ever high PSC device containing PCDTBT with a PCE value of $6.1 \%$ and an internal quantum efficiency approaching ca. $100 \% .{ }^{4(c)}$

The five-membered heterocyclic electron deficient moiety, that is, thiazole, induces larger $\pi-\pi$ stacking and higher coplanarity $^{17,18}$ in D-A polymers so as to have a stronger tendency to self-assemble into stacked solid structures, which not only minimize steric hindrances but also provide extended conjugation lengths. Introduction of thiazole units with electron-withdrawing imine nitrogen $(-\mathrm{C}=\mathrm{N})$ generally enhances the electron-accepting (n-doping) properties of the D-A polymers. Moreover, thiazole-based polymers exhibit high oxidative stabilities which favor the polymers to lower its HOMO energy level and thus to increase their open circuit voltages. ${ }^{20}$ Though Shim et al. firstly reported that the polymer containing bithiazole and fluorine units achieved a low PCE value of $0.52 \%,{ }^{20(b)}$ we reached a much higher PCE value of $3.04 \%$ using a copolymer containing bithiazole and cyclopentadithiophene units recently. ${ }^{21(a)}$ As a consequence, the copolymers containing the planar electron-withdrawing bithiazole units as acceptors and 2,7-carbazole units as donors to produce $\mathrm{D}-\mathrm{A}$ polymers will be very interesting LBG polymers for the applications of PSCs. In addition, $\mathrm{Li}$ et al. have newly reported one D-A copolymer containing 2,7-carbazole and bithiazole moieties as electron-donor and electron-acceptor segments, respectively, but only possessed a maximum PCE value of $0.30 \%{ }^{10(e)}$

In this article, we synthesized and characterized a series of copolymers consisting of a planar 2,7-carbazole moiety with conducting thiophene (thiophene or bithiophene) as electron-donating segments and bithiazole derivatives as electron-accepting segments. The copolymers were synthesized by $\mathrm{Pd}(0)$-catalyzed Stille coupling polymerization with 1:1 (molar ratio) donor-acceptor ratio. The resulting polymers P1-P4 exhibited broad absorption bands located in the UVvisible regions from 300 to $600 \mathrm{~nm}$ with optical band gaps of 1.99-1.93 eV. From the preliminary investigation, the photovoltaic (PV) performance of the PSC device containing P4 (as an electron donor) blended with $\mathrm{PC}_{71} \mathrm{BM}$ (as an acceptor) showed the best PCE value of $1.01 \%$ with a $V_{\text {oc }}=0.60 \mathrm{~V}$, a $J_{\mathrm{sc}}=4.83 \mathrm{mAcm}^{-2}$, and a fill factor (FF) of $35.0 \%$ measured under $100 \mathrm{~mW} / \mathrm{cm}^{2}$ of AM 1.5 white-light illumination.

\section{EXPERIMENTAL}

\section{Materials}

All chemicals and solvents were reagent grades and purchased from Aldrich, ACROS, Fluka, TCI, TEDIA, and Lancaster Chemical Co. Toluene and tetrahydrofuran (THF) were distilled from sodium-benzophenone under nitrogen before use. Unless otherwise specified, the other solvents were degassed by nitrogen $1 \mathrm{~h}$ before use. All the other chemicals were used as received.

\section{Measurements and Characterization}

${ }^{1} \mathrm{H}$ and ${ }^{13} \mathrm{C}$ NMR spectra were recorded on a Varian Unity $300 \mathrm{MHz}$ spectrometer using $\mathrm{CDCl}_{3}$ solvent and chemical shifts were reported as $\delta$ values (ppm) relative to an internal tetramethylsilane standard. Elemental analyses were performed on a HERAEUS CHN-OS RAPID elemental analyzer. Thermogravimetric analyses (TGA) were conducted with a TA Instruments Q500 at a heating rate of $10{ }^{\circ} \mathrm{C} / \mathrm{min}$ under nitrogen. Gel permeation chromatography (GPC) analyses were conducted on a Waters 1515 separation module using polystyrene as a standard and THF as an eluent. UV-Visible (UV-vis) absorption spectra were recorded in dilute THF solutions $\left(10^{-6} \mathrm{M}\right)$ on a HP G1103A spectrophotometer. Thin films for UV-vis measurements were spin-coated on a glass substrate from THF solutions with a concentration of $5 \mathrm{mg}$ / mL. Cyclic voltammetry (CV) measurements were performed using a BAS 100 electrochemical analyzer with a standard three-electrode electrochemical cell in a $0.1 \mathrm{M}$ tetrabutylammonium hexafluorophosphate $\left(\mathrm{TBAPF}_{6}\right)$ solution (in acetonitrile) at room temperature with a scanning rate of 100 $\mathrm{mV} / \mathrm{s}$. During the $\mathrm{CV}$ measurements, the solutions were purged with nitrogen for $30 \mathrm{~s}$. In each case, a carbon working electrode coated with a thin layer of copolymers, a platinum wire as the counter electrode, and a silver wire as the quasi-reference electrode were used, and $\mathrm{Ag} / \mathrm{AgCl}(3 \mathrm{M} \mathrm{KCl})$ electrode was served as a reference electrode for all potentials quoted herein. The redox couple of ferrocene/ferrocenium ion $\left(\mathrm{Fc} / \mathrm{Fc}^{+}\right)$was used as an external standard. The corresponding HOMO and LUMO levels were calculated using $E_{\text {ox/onset }}$ and $E_{\text {red/onset }}$ for experiments in solid films of polymers, which were performed by drop-casting films with the similar thickness from THF solutions (ca. $5 \mathrm{mg} / \mathrm{mL}$ ). The LUMO levels of $\mathrm{PC}_{61} \mathrm{BM}$ or $\mathrm{PC}_{71} \mathrm{BM}$ employed were in accordance with the literature data. The onset potentials were determined 
from the intersections of two tangents drawn at the rising currents and background currents of the CV measurements.

\section{Device Fabrication and PV Measurements of PSCs}

The polymer PV cells in this study were composed of an active layer of blended polymers (P1-P4:PCBM) in solid films, which were sandwiched between a transparent indium tin oxide (ITO) anode and a metal cathode. Before the device fabrication, ITO-coated glass substrates $\left(1.5 \times 1.5 \mathrm{~cm}^{2}\right)$ were ultrasonically cleaned in detergent, deionized water, acetone, and isopropyl alcohol sequentially. After routine solvent cleaning, the substrates were treated with UV ozone for 15 min. Then, a modified ITO surface was obtained by spincoating a layer of poly(ethylene dioxythiophene):polystyrenesulfonate (PEDOT:PSS) ( $\sim 30 \mathrm{~nm})$. After baking at $130{ }^{\circ} \mathrm{C}$ for $1 \mathrm{~h}$, the substrates were transferred to a nitrogen-filled glove box. The PSC devices were fabricated by spin-coating solutions of blended polymers (P1-P4):PCBM (with various weight ratios of a copolymer and one of PCBMs, that is, $\mathrm{PC}_{61} \mathrm{BM}$ or $\mathrm{PC}_{71} \mathrm{BM}$ ) onto the PEDOT:PSS modified substrates at $1500 \mathrm{rpm}$ for $60 \mathrm{~s}$ (ca. $80 \mathrm{~nm}$ ), and placed in a covered glass Petri dish. Initially, the blended polymer solutions were prepared by dissolving both copolymers and $\mathrm{PC}_{61} \mathrm{BM}$ (with a 1:1 weight ratio) initially and then with various weight ratios for the optimum copolymer with $\mathrm{PC}_{71} \mathrm{BM}$ in 1,2 dichlorobenzene (DCB) $(20 \mathrm{mg} / \mathrm{mL}$ ), followed by continuous stirring for $12 \mathrm{~h}$ at $50{ }^{\circ} \mathrm{C}$. In the slow-growth approach, blended polymers in solid films were kept in the liquid phase after spincoating by using the solvent with a high boiling point. Finally, a calcium layer $(30 \mathrm{~nm})$ and a subsequent aluminum layer $(100 \mathrm{~nm})$ were thermally evaporated through a shadow mask at a pressure below $6 \times 10^{-6}$ Torr. All PSC devices were prepared and measured under ambient conditions, where the active area of the devices was $0.12 \mathrm{~cm}^{2}$. The solar cell testing was done inside a glove box under simulated AM $1.5 \mathrm{G}$ irradiation $\left(100 \mathrm{~mW} / \mathrm{cm}^{2}\right)$ using a Xenon lamp-based solar simulator (Thermal Oriel 1000W). The external quantum efficiency (EQE) action spectrum was obtained at shortcircuit condition. The light source was a $450 \mathrm{~W}$ Xe lamp (Oriel Instrument, model 6266) equipped with a water-based IR filter (Oriel Instrument, model 6123NS). The light output from the monochromator (Oriel Instrument, model 74100) was focused onto the PV cell under test.

\section{Synthesis of Monomers and Polymers 4,4'-Dibromo-2-nitrobiphenyl (1)}

4,4'-Dibromobiphenyl (20 g, $64 \mathrm{mmol})$ in $300 \mathrm{~mL}$ of glacial acetic acid was heated $\left(100{ }^{\circ} \mathrm{C}\right)$ to dissolve completely. Then, $90 \mathrm{~mL}$ of fuming nitric acid was added dropwise for a period of $30 \mathrm{~min}$. The resulting mixture was further stirred vigorously for $1 \mathrm{~h}$ at $100{ }^{\circ} \mathrm{C}$ to get a reddish brown precipitate. The reaction mixture was cooled to room temperature and poured into ice cold water. The precipitate was filtered and washed with excess of water, then the obtained product was further purified by recrystalization from ethanol to get a yellow solid (20.30 g, 88.72\%). ${ }^{1} \mathrm{H}$ NMR (300 $\mathrm{MHz} \mathrm{CDCl}_{3}$ ), $\delta$ (ppm): 8.03 (d, $J=3.0 \mathrm{~Hz}, 1 \mathrm{H}), 7.75(\mathrm{dd}, J=9.0 \mathrm{~Hz}, J=3.0$ $\mathrm{Hz}, 1 \mathrm{H}), 7.55(\mathrm{~d}, J=9.0 \mathrm{~Hz}, 2 \mathrm{H}), 7.30(\mathrm{~d}, J=9.0 \mathrm{~Hz}, 1 \mathrm{H})$, $7.15(\mathrm{~d}, J=6.0 \mathrm{~Hz}, 2 \mathrm{H})$.

\section{2,7-Dibromocarbazole (2)}

Mixture of compound 2 (20 g, $56.02 \mathrm{mmol}$ ) and triphenylphosphine (36.73 g, $140.05 \mathrm{mmol}$ ) were dissolved in 220 $\mathrm{mL}$ of DCB and the reaction mixture was refluxed for $12 \mathrm{~h}$. The excess DCB was removed by high vacuum distillation and the residue was purified by column chromatography (Silica gel) using a mixture of hexane:ethyl acetate (7:3) to get a white solid $(12.90 \mathrm{~g}, 70.87 \%) .{ }^{1} \mathrm{H}$ NMR $(300 \mathrm{MHz}$, $\mathrm{CDCl}_{3}$ ), $\delta(\mathrm{ppm}): 8.08(\mathrm{br}, 1 \mathrm{H}), 7.87(\mathrm{~d}, J=8.7 \mathrm{~Hz}, 2 \mathrm{H}), 7.56$ $(\mathrm{d}, J=1.5 \mathrm{~Hz}, 2 \mathrm{H}), 7.35(\mathrm{dd}, J=1.8 \mathrm{~Hz}, J=8.4 \mathrm{~Hz}, 2 \mathrm{H})$.

\section{1-Hexylheptanol (3)}

In a $500 \mathrm{~mL}$ flame-dried two-neck round bottom flask, ethyl formate $(10 \mathrm{~mL}, 123.78 \mathrm{mmol})$ was dissolved in $100 \mathrm{~mL}$ of anhydrous THF and cooled to $-78{ }^{\circ} \mathrm{C}$ under $\mathrm{N}_{2}$ atmosphere. A freshly prepared hexylmagnesium bromide, which was obtained by adding 1-bromohexane (48.90 mL, 346.59 mmol) to a suspension of magnesium turning (10.40 g, $433.24 \mathrm{mmol})$ in dry THF $(150 \mathrm{~mL})$, was added dropwise into the previous solution, and then the reaction mixture was stirred overnight at room temperature. The reaction was quenched by the addition of $\mathrm{MeOH}$, and then followed by adding saturated aqueous $\mathrm{NH}_{4} \mathrm{Cl}$. The crude compound was extracted three times with ethyl acetate. The combined organic fractions were washed with brine, dried over $\mathrm{MgSO}_{4}$, and concentrated by rotary evaporation. After vacuum distillation, the final compound was isolated as a white solid (21.87 g, 87.94\%). ${ }^{1} \mathrm{H}$ NMR $\left(\mathrm{CDCl}_{3}, 300 \mathrm{MHz}\right): \delta$ (ppm): 3.58 (m, 1H), $1.46-1.25(\mathrm{~m}, 21 \mathrm{H}), 0.87(\mathrm{t}, J=6.4 \mathrm{~Hz}, 6 \mathrm{H})$.

\section{Tridecan-7-yl 4-Methylbenzenesulfonate (4)}

In a $250 \mathrm{~mL}$ flame-dried two neck round bottom flask, 1hexylheptanol (10.0 g, $49.91 \mathrm{mmol}^{2}, \mathrm{Et}_{3} \mathrm{~N}$ (17.40 mL, 124.77 mmol), and $\mathrm{Me}_{3} \mathrm{~N} \cdot \mathrm{HC} 1$ (4.77 $\mathrm{g}, 49.91 \mathrm{mmol}$ ) were mixed in $40 \mathrm{~mL}$ of $\mathrm{CH}_{2} \mathrm{Cl}_{2}$ and then cooled to $0-5{ }^{\circ} \mathrm{C}$. A solution of $p$ toluenesulfonyl chloride (11.90 g, $62.38 \mathrm{mmol}$ ) in $\mathrm{CH}_{2} \mathrm{Cl}_{2}$ (39 $\mathrm{mL}$ ) was added dropwise over $90 \mathrm{~min}$ and kept the reaction at room temperature. After $2 \mathrm{~h}$, water was added and the crude compound was extracted with $\mathrm{CH}_{2} \mathrm{Cl}_{2}$. The organic fraction was washed with water and brine, and dried over $\mathrm{MgSO}_{4}$, and concentrated by rotary evaporation. Subsequently, the crude product was purified by column chromatography (Silica gel, hexane/ethylacetate 9:1) to yield a viscous colorless liquid (15.15 g, 85.60\%). ${ }^{1} \mathrm{H}$ NMR $(300 \mathrm{MHz}$, $\left.\mathrm{CDCl}_{3}\right): \delta(\mathrm{ppm}): 7.79(\mathrm{~d}, J=8.2 \mathrm{~Hz}, 2 \mathrm{H}) ; 7.32(\mathrm{~d}, J=8.1 \mathrm{~Hz}$, $2 \mathrm{H}) ; 4.53(\mathrm{~m}, J=6.0 \mathrm{~Hz}, 1 \mathrm{H}) ; 2.43(\mathrm{~s}, 3 \mathrm{H}) ; 1.52(\mathrm{~m}, 4 \mathrm{H})$; $1.22(\mathrm{~m}, 20 \mathrm{H}) ; 0.88(\mathrm{t}, J=6.9 \mathrm{~Hz}, 6 \mathrm{H})$.

\section{2,7-Dibromo-9-(Tridecan-7-yl)-9H-Carbazole (5)}

2,7-Dibromocarbazole (4.0 g, $12.30 \mathrm{mmol}$ ) and potassium hydroxide powder (3.45 g, $61.50 \mathrm{mmol})$ were dissolved in 50 $\mathrm{mL}$ of dimethylsulfoxide (DMSO) at $60{ }^{\circ} \mathrm{C}$. Then, a solution of tridecan-7-yl 4-methylbenzenesulfonate (6.25 g, 18.45 mmol) with $30 \mathrm{~mL}$ of DMSO was added dropwise through a dropping funnel over $1.5-2 \mathrm{~h}$ and stirred overnight. The reaction mixture was cooled to room temperature and poured into $500 \mathrm{~mL}$ of water. The crude compound was extracted with ethylacetate and washed with brine. The combined organic layer was dried over $\mathrm{MgSO}_{4}$ and concentrated 

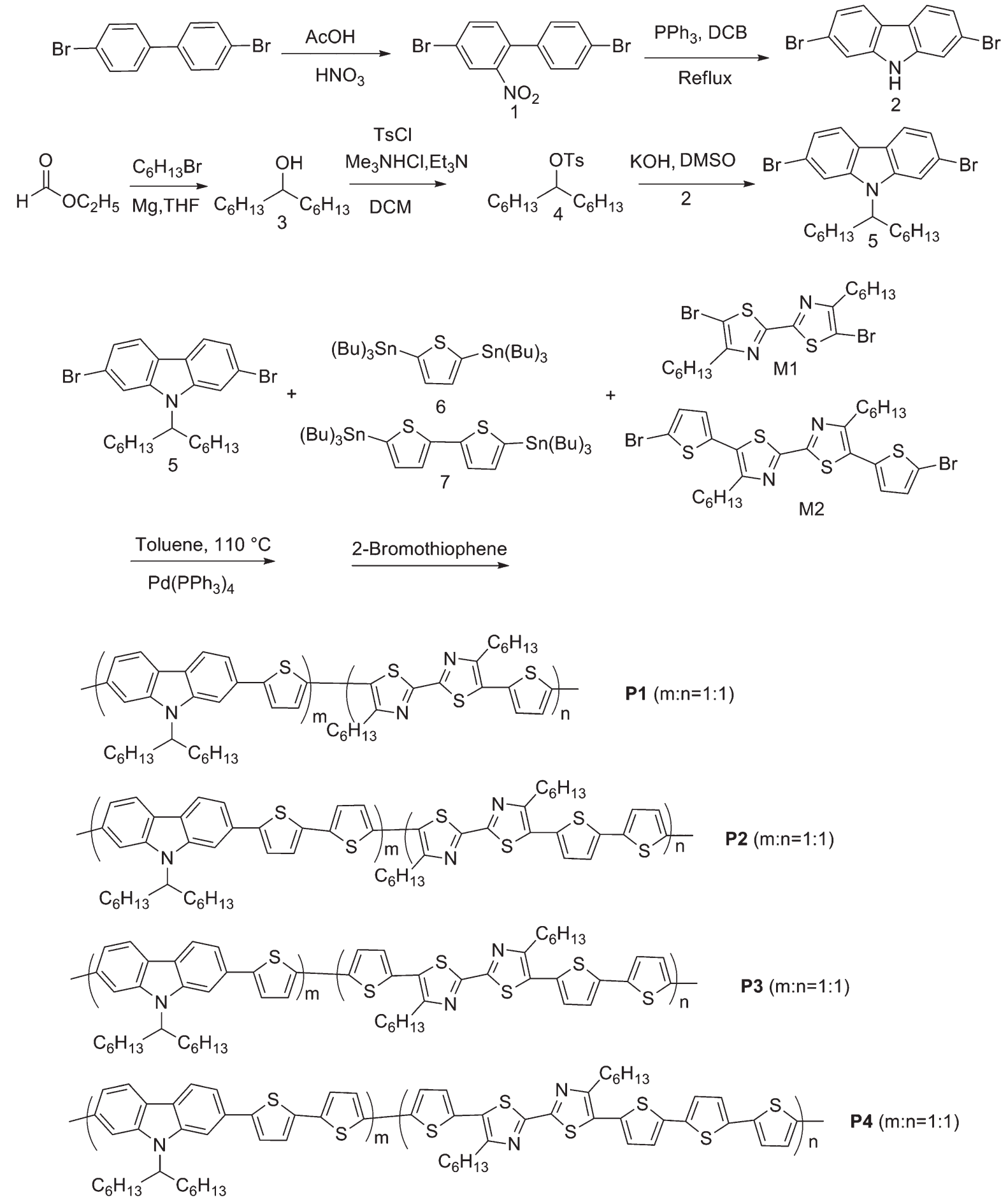

SCHEME 1 Synthetic schemes of compound $\mathbf{5}$ and polymers P1-P4.

in rotary evaporator. The crude compound was purified by column chromatography (silica gel) using hexane as an eluent to give a white solid (4.62 g, 74.03\%). ${ }^{1} \mathrm{H}$ NMR (300 $\mathrm{MHz}, \mathrm{CDCl}_{3}$ ): $\delta$ (ppm): $7.90(\mathrm{br}, 2 \mathrm{H}) ; 7.70(\mathrm{~s}, 1 \mathrm{H}) ; 7.54(\mathrm{~s}$, $1 \mathrm{H}) ; 7.33(\mathrm{~d}, J=6.0 \mathrm{~Hz}, 2 \mathrm{H}) ; 4.42(\mathrm{~m}, 1 \mathrm{H}) ; 2.19(\mathrm{~m}, 2 \mathrm{H})$; 1.91 (m, 2H); $1.15(\mathrm{~m}, 16 \mathrm{H}) ; 0.83(\mathrm{t}, J=6.3 \mathrm{~Hz}, 6 \mathrm{H}) .{ }^{13} \mathrm{C}$ NMR (75 MHz, $\left.\mathrm{CDCl}_{3}\right): \delta(\mathrm{ppm}): 130.61 ; 130.15 ; 122.58$; $121.71 ; 121.48 ; 114.75 ; 112.39 ; 57.22 ; 33.76 ; 31.79 ; 29.25$;
26.98; 22.76; 14.23; EIMS (m/z): Anal. Calcd for $\mathrm{C}_{25} \mathrm{H}_{33} \mathrm{Br}_{2} \mathrm{~N}$ : C, 59.18; H, 6.56; N, 2.76. Found: C, 59.58; H, 6.12; N, 2.77. MS (FAB): m/z [M+] 505.0; calcd m/z [M+] 505.10.

\section{General Synthetic Procedures of Polymers P1-P4}

The synthetic route of copolymers is shown in Scheme 1. Into a $25 \mathrm{~mL}$ two-necked flask, 2,7-dibromo-9-(tridecan-7yl)-9H-carbazole, 2,5-bis(tributylstannyl)thiophene (or 5,5'- 
bis(tributylstannyl)-2,2'-bithiophene), and 5,5'-dibromo-4,4'dihexyl-2,2'-bithiazole (or 5,5'-bis(5-bromothiophen-2-yl)$4,4^{\prime}$-dihexyl-2,2'-bithiazole were added. The mixture was deoxygenated with nitrogen for $30 \mathrm{~min}$, after which dry toluene $(15 \mathrm{~mL})$ and $\mathrm{Pd}\left(\mathrm{PPh}_{3}\right)_{4}(1 \mathrm{~mol} \%)$, was transferred into the mixture in a dry environment. The reaction mixture was stirred at $110{ }^{\circ} \mathrm{C}$ for 3 days, and then an excess amount of 2-bromothiophene was added to end-cap the trimethylstannyl groups for $4 \mathrm{~h}$. The reaction mixture was cooled to $40{ }^{\circ} \mathrm{C}$ and added slowly into a vigorously stirred mixture of methanol/acetone (3:1). The polymers were collected by filtration and reprecipitation from methanol. The crude polymers were further purified by washing with acetone and EA for 2 days in a Soxhlet apparatus to remove oligomers and catalytic residues.

\section{P1}

Following the general polymerization procedure, compound 5 ( 0.5 equiv), M1 ( 0.5 equiv), and compound 6 (1.0 equiv) were used in this polymerization to acquire a red powder. Yield: $72 \%$. GPC: $M_{\mathrm{w}}$ : 41,900; polydispersity index (PDI): 1.62; ${ }^{1} \mathrm{H}$ NMR (300 MHz, $\mathrm{CDCl}_{3}$ ): $\delta$ (ppm) 8.10 (broad), 7.79-7.39 (broad), 7.12 (s), 4.62 (broad), 2.84 (broad), 1.83 (broad), 1.75-0.80 (broad), 0.77-0.61(broad). Anal. Calcd for $\left(\mathrm{C}_{51} \mathrm{H}_{65} \mathrm{~N}_{3} \mathrm{~S}_{4}\right)_{\mathrm{n}}$ : C, 72.21; H, 7.72; N, 4.95. Found: C, 71.81; H, $7.59 ; \mathrm{N}, 4.87$.

\section{P2}

Following the general polymerization procedure, compound 5 ( 0.5 equiv), M2 ( 0.5 equiv), and compound 7 (1.0 equiv) were used in this polymerization to acquire a deep red powder. Yield: 69\%. GPC: $M_{\mathrm{w}}$ : 25,100; PDI: 1.36 ; ${ }^{1} \mathrm{H}$ NMR $(300$ $\mathrm{MHz}, \mathrm{CDCl}_{3}$ ): $\delta$ (ppm) 8.10 (broad), 7.89-7.22 (broad), 7.12 (broad), 4.62 (broad), 2.97 (broad), 1.83 (broad), 1.75-0.80 (broad), 0.77-0.61(broad). Anal. Calcd for $\left(\mathrm{C}_{59} \mathrm{H}_{69} \mathrm{~N}_{3} \mathrm{~S}_{6}\right)_{\mathrm{n}}$ : C, 69.98; H, 6.87; N, 4.15. Found: C, 69.18; H, 6.79; N, 4.25.

\section{P3}

Following the general polymerization procedure, compound 5 (0.5 equiv), M1 (0.5 equiv), and compound 6 (1.0 equiv) were used in this polymerization to acquire a black powder. Yield: 66\%. GPC: $M_{\mathrm{w}}$ : 8,880; PDI: $1.20 ;{ }^{1} \mathrm{H}$ NMR $(300 \mathrm{MHz}$, $\left.\mathrm{CDCl}_{3}\right): \delta$ (ppm) 8.10 (broad), 7.79-7.19 (broad), 7.15 (broad), 4.62 (broad), 2.99 (broad), 1.85 (broad), 1.75-0.80 (broad), 0.77-0.61(broad). Anal. Calcd for $\left(\mathrm{C}_{59} \mathrm{H}_{69} \mathrm{~N}_{3} \mathrm{~S}_{6}\right)_{\mathrm{n}}$ : C, 69.98; H, 6.87; N, 4.15. Found: C, 69.30; H, 6.98; N, 4.22.

\section{P4}

Following the general polymerization procedure, compound 5 ( 0.5 equiv), M2 ( 0.5 equiv), and compound 7 (1.0 equiv) were used in this polymerization to acquire a black powder. Yield: 64\%. GPC: $M_{\mathrm{w}}$ : 8600; PDI: 1.19; ${ }^{1} \mathrm{H}$ NMR $(300 \mathrm{MHz}$, $\left.\mathrm{CDCl}_{3}\right): \delta$ (ppm) 8.10 (broad), 7.79-7.39 (broad), 7.11 (broad), 4.59 (broad), 2.97 (broad), 1.81 (broad), 1.75-0.80 (broad), 0.77-0.61(broad). Anal. Calcd for $\left(\mathrm{C}_{67} \mathrm{H}_{73} \mathrm{~N}_{3} \mathrm{~S}_{8}\right)_{\mathrm{n}}$ : C, 68.38; H, 6.25; N, 3.57. Found: C, 67.82; H, 6.38; N, 3.64.
TABLE 1 Molecular Weights and Thermal Properties of Polymers P1-P4

\begin{tabular}{lrllll}
\hline Polymer & $M_{\mathrm{w}}{ }^{\mathrm{a}}$ & \multicolumn{1}{c}{$M_{\mathrm{n}}{ }^{\mathrm{a}}$} & $\begin{array}{l}\mathrm{PDI}^{\mathrm{a}} \\
\left(M_{\mathrm{w}} / M_{\mathrm{n}}\right)\end{array}$ & $\begin{array}{l}\text { Yield } \\
(\%)\end{array}$ & $\begin{array}{l}T_{\mathrm{d}}{ }^{\mathrm{b}} \\
\left({ }^{\circ} \mathrm{C}\right)\end{array}$ \\
P1 & 41,900 & 25,900 & 1.62 & 72 & 452 \\
P2 & 25,100 & 18,500 & 1.36 & 69 & 423 \\
P3 & 8,900 & 7,400 & 1.20 & 66 & 418 \\
P4 & 8,600 & 7,200 & 1.19 & 64 & 361
\end{tabular}

a Molecular weights $\left(M_{\mathrm{n}}\right.$ and $\left.M_{\mathrm{w}}\right)$ and polydispersity index (PDI) values were measured by GPC, using THF as an eluent, polystyrene as a standard. $M_{\mathrm{n}}$, number average molecular weight; $M_{\mathrm{w}}$, weight average molecular weight.

${ }^{b}$ Temperature $\left({ }^{\circ} \mathrm{C}\right)$ at $5 \%$ weight loss measured by TGA at a heating rate of $10{ }^{\circ} \mathrm{C} / \mathrm{min}$ under nitrogen.

\section{RESULTS AND DISCUSSION}

\section{Syntheses and Characterization}

The synthetic routes of 2,7-carbazole-based donor monomer (compound 5) and polymers P1-P4 are outlined in Scheme 1. Compound 5 was adequately characterized by ${ }^{1} \mathrm{H}$ NMR, ${ }^{13} \mathrm{C}$ NMR, MS spectroscopies, and elemental analyses. The thiophene- and bithiophene-based donor monomers (compounds 6 and 7, respectively) were prepared according to the methods described elsewhere. ${ }^{22}$ In addition, the synthetic procedures of bithiazole-based acceptor monomers M1 and M2 were also reported earlier by our group. ${ }^{21(a)}$ In this study, polymers P1-P4 consisting of 2,7-carbazole and thiophene (or 2,2'-bithiophene) as electron-donating moeities and bithiazole as electron-accepting moieties were synthesized by $\mathrm{Pd}(0)$-catalyzed Stille coupling polymerization in toluene at $110{ }^{\circ} \mathrm{C}$ with a feed-in molar ratio of $\mathrm{m}: \mathrm{n}=1: 1$.

All these copolymers are readily soluble in common organic solvents such as chloroform, THF, and chlorobenzene at room temperature and completely soluble in high boiling point solvents (e.g., chlorobenzene) at high temperature. The molecular weights of polymers P1-P4 determined by GPC against polystyrene standards in THF are summarized in Table 1. These results show that considerable molecular weights with high yields (64-72\% after Soxhlet extractions) were obtained in these copolymers, where the average molecular weights $\left(M_{\mathrm{w}}\right)$ were in the range of 41,900-8600 with PDI (PDI $=M_{\mathrm{w}} / M_{\mathrm{n}}$ ) values of 1.62-1.19. The thermal stabilities of conjugated polymers play an important role for optoelectronic applications. As shown in Figure 1, the thermal stabilities of polymers P1-P4 were investigated by TGA, and their corresponding results are summarized in Table 1. All polymers showed good thermal stabilities and exhibited $T_{\mathrm{d}}$ values (temperatures at $5 \%$ weight loss by a heating rate of $10{ }^{\circ} \mathrm{C} /$ min under nitrogen) between 361 and $452{ }^{\circ} \mathrm{C}$, where the $T_{\mathrm{d}}$ value was reduced as the molecular weight decreased. ${ }^{23}$

\section{Optical Properties}

The photophysical features of the copolymers were investigated by UV-vis absorption spectroscopy in dilute THF solutions and spin-coated films on glass substrates, which are 


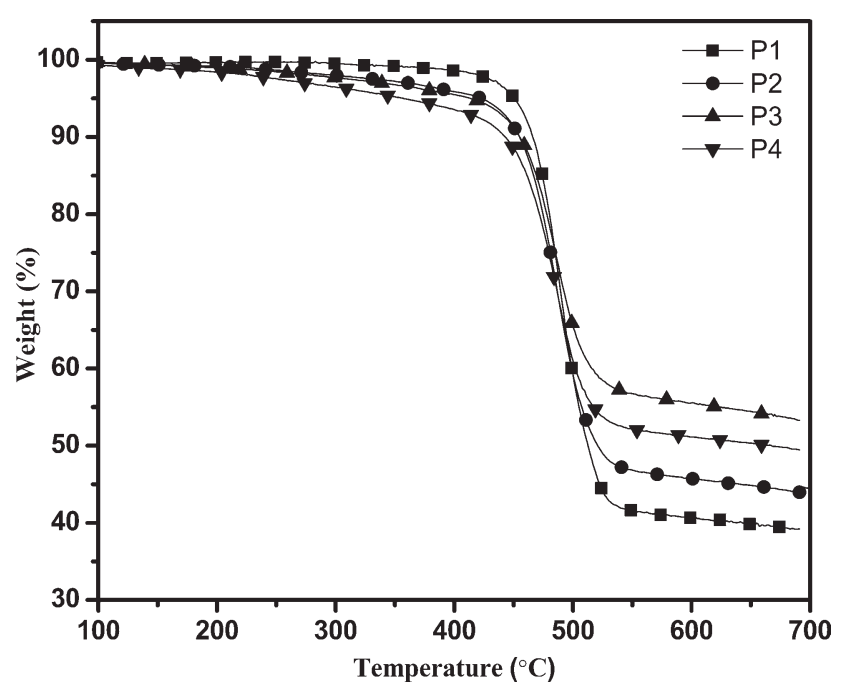

FIGURE 1 TGA measurements of polymers P1-P4 with a heating rate of $10^{\circ} \mathrm{C} / \mathrm{min}$.

presented in Figures 2(a) and 2(b), respectively. The normalized absorption spectra of polymers P1-P4 and their optical data, including the absorption wavelengths $\left(\lambda_{\text {max,abs }}\right)$ and the optical band gaps $\left(E_{\mathrm{g}}^{\mathrm{opt}}\right)$, and absorpation coefficients $\left(\alpha_{\max }\right)$, are summarized in Table 2. All polymers (P1-P4) shows relatively high absorption coefficients $\left(\alpha_{\max }\right.$, calculated from Beer's law) with the range of 4.2-5.7 and 2.0-4.2 $\times 10^{4} \mathrm{M}^{-1}$ $\mathrm{cm}^{-1}$ in dilute solutions and solid films, respectively, which assures the copolymers to harvest enough photons. The absorption wavelengths $\left(\lambda_{\text {max,abs }}\right)$ of polymers P1, P2, P3, and P4 in dilute solutions were located at 455, 459, 464, and $466 \mathrm{~nm}$, respectively, which can be attributed to $\pi-\pi^{*}$ transition of the conjugated copolymer backbones and the $\pi-\pi$ interaction between the electron donor (carbazole) and acceptor (bithiazole) units. It is obvious that, by tuning the numbers of thiophene units in the polymer-conjugated heterocyclic main-chains, the absorption spectra of carbazolebased copolymers will be effectively influenced (in both solutions and solid films). In contrast to solutions (see Table 2), the absorption wavelengths $\left(\lambda_{\text {max,abs }}\right)$ of polymers P1-P4 in solid films were found red-shifted to the range of 463-503
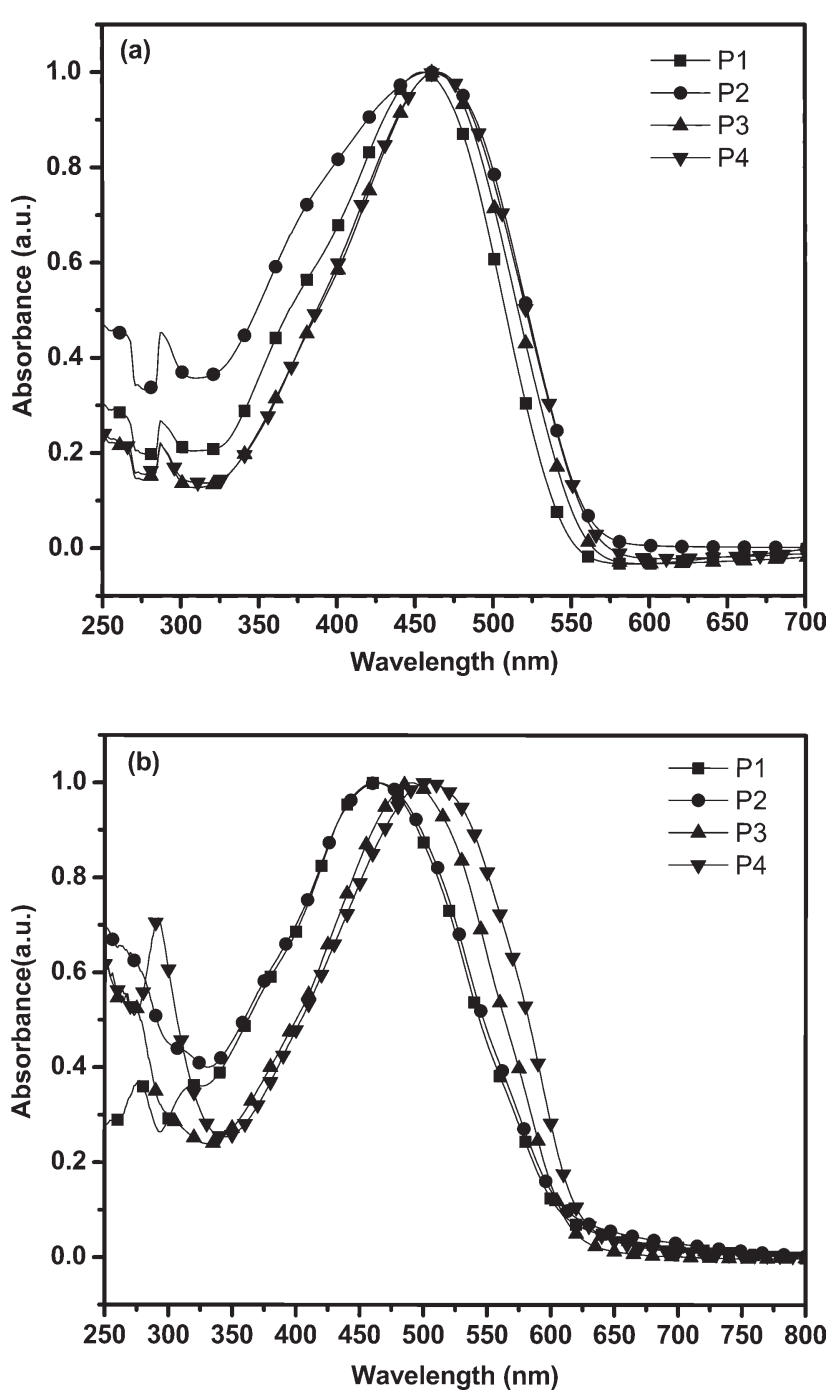

FIGURE 2 Normalized absorption spectra of P1-P4 in dilute chloroform solutions.

nm obviously. These red-shifted wavelengths in solid films are ascribed to the interchain associations and $\pi-\pi$ stackings of these copolymers as well as the highly rigid and planar

TABLE 2 Optical and Electrochemical Properties of Polymers P1-P4

\begin{tabular}{|c|c|c|c|c|c|c|c|c|c|}
\hline \multirow[b]{2}{*}{ Polymer } & \multirow{2}{*}{ 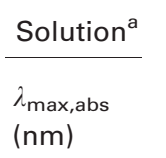 } & \multicolumn{2}{|c|}{ Solid Film ${ }^{b}$} & \multicolumn{2}{|c|}{$\alpha_{\max }\left(\times 10^{4} \mathrm{M}^{-1} \mathrm{~cm}^{-1}\right)$} & \multicolumn{2}{|c|}{ Energy Levels } & \multicolumn{2}{|c|}{ Band Gaps ${ }^{\mathrm{g}}$} \\
\hline & & $\begin{array}{l}\lambda_{\max , a b s} \\
(\mathrm{~nm})\end{array}$ & $\begin{array}{l}\lambda_{\text {onset,abs }} \\
(\mathrm{nm})\end{array}$ & Solution $^{d}$ & $\begin{array}{l}\text { Solid } \\
\text { Film }\end{array}$ & $\begin{array}{l}E_{\text {onset }}^{\text {ox }} \\
(\mathrm{V}) / \mathrm{HOMO}^{\mathrm{f}}(\mathrm{eV})\end{array}$ & $\begin{array}{l}E_{\text {onset }}^{\text {red }} \\
(\mathrm{V}) / \text { LUMO }^{f}(\mathrm{eV})\end{array}$ & $\begin{array}{l}E_{\mathrm{g}}^{\mathrm{ec}} \\
(\mathrm{eV})\end{array}$ & $\begin{array}{l}E_{\mathrm{g}}^{\mathrm{opt}} \\
(\mathrm{eV})\end{array}$ \\
\hline P1 & $(314)^{c} 455$ & 314,463 & 623 & 4.2 & 2.0 & $1.07 /-5.42$ & $-0.75 /-3.60$ & 1.82 & 1.99 \\
\hline P2 & $(364)^{c} 459$ & 464 & 632 & 4.5 & 2.1 & $1.05 /-5.40$ & $-0.76 /-3.59$ & 1.81 & 1.96 \\
\hline P3 & 464 & 490 & 626 & 5.2 & 3.4 & $1.03 /-5.38$ & $-0.77 /-3.58$ & 1.80 & 1.98 \\
\hline P4 & 466 & 290,504 & 642 & 5.7 & 4.2 & $0.99 /-5.34$ & $-0.80 /-3.55$ & 1.79 & 1.93 \\
\hline \multicolumn{4}{|c|}{$\begin{array}{l}\text { a In THF dilute solution. } \\
\text { b Spin coated from THF solution on glass surface. } \\
{ }^{c} \text { Shoulder peak. } \\
\text { d Absorption coefficient determined at } \lambda_{\max } \text { in THF. } \\
\text { e Absorption coefficient of the solid film at } \lambda_{\max }\end{array}$} & & \multicolumn{5}{|c|}{ 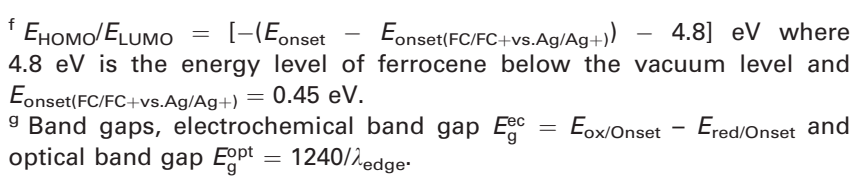 } \\
\hline
\end{tabular}




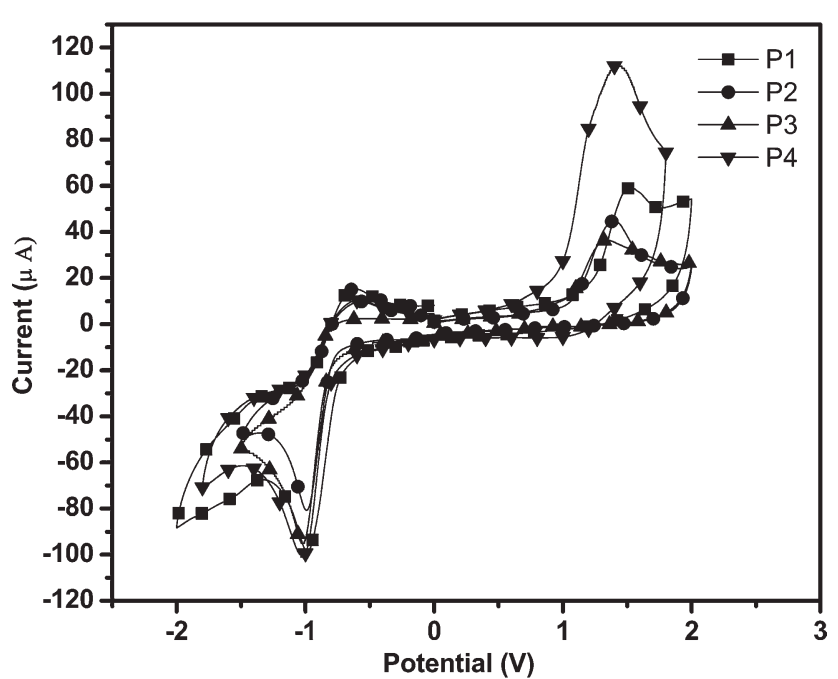

FIGURE 3 Cyclic voltammograms of P1-P4 in solid films at a scan rate of $100 \mathrm{mV} / \mathrm{s}$.

segments of polymer backbones. ${ }^{24,6(b)}$ Moreover, the red shifts of absorption wavelengths from solutions to solid films are 8, 5, 26, $38 \mathrm{~nm}$ for polymers P1-P4, respectively. Hence, the larger numbers of thiophene units in P3 and P4 with longer conjugation lengths induced stronger $\pi-\pi$ stackings in solid films, and thus to have larger red-shifted absorption wavelengths. $^{25}$

As shown in Table 2, the optical band gaps ( $\left.E_{\mathrm{g}}^{\mathrm{opt}}\right)$ of polymers P1-P4 in solid films were found in the range of 1.93$1.99 \mathrm{eV}$, which were determined from the cutoffs of the absorption wavelengths. The optical band gaps of the copolymers were reduced from P1 to P2 and from P3 to P4 owing to the enhancement of electron donating capabilities, because more thiophene units and longer conjugation lengths were introduced in the polymer backbones. ${ }^{6(b), 23}$ These results imply that the light harvesting capabilities along with optical band gaps can be tuned by electron D-A segments in the polymer backbone, which is one of the efficient ways to design the organic PV materials.

\section{Electrochemical Properties}

To investigate the redox behavior of the random copolymers and determine their electronic states (i.e., HOMO/LUMO levels), the electrochemical properties of polymers P1-P4 were investigated by $\mathrm{CV}$. The oxidation and reduction cyclic voltammograms of the copolymers are shown in the Figure 3. The electrochemical properties, such as onset potentials of oxidation and reduction, that is, the estimated positions of the upper edges of the valence band (HOMO) and the lower edges of the conduction band (LUMO), respectively, and electrochemical band gaps are summarized in Table 2. The CV measurements were carried out in a $0.1 \mathrm{M} \mathrm{TBAPF}_{6}$ solution (in acetonitrile) at a scan rate of $100 \mathrm{mV} / \mathrm{s}$ under nitrogen. A carbon electrode, which was coated with the polymer film by dip coating, was used as a working electrode and $\mathrm{Ag} /$ $\mathrm{AgCl}$ was served as a reference electrode, and it was calibrated by ferrocene $\left(E_{\text {ferrocene }}^{1 / 2}=0.45 \mathrm{mV}\right.$ versus $\left.\mathrm{Ag} / \mathrm{AgCl}\right)$.
The HOMO and LUMO energy levels were estimated by the oxidation and reduction potentials from the reference energy level of ferrocene ( $4.8 \mathrm{eV}$ below the vacuum level) according to the following equation ${ }^{21(\mathrm{a}), 26}: E_{\mathrm{HOMO}} / E_{\mathrm{LUMO}}=\left[-\left(E_{\text {onset }}-\right.\right.$ $\left.\left.E_{\text {onset(FC/FC }+ \text { vs. } \mathrm{Ag} / \mathrm{Ag}+)}\right)-4.8\right] \mathrm{eV}$ and band gap $=E_{\text {onset/ox }}-$

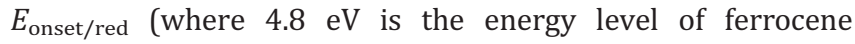
below the vacuum level and $E_{\text {onset(FC/FC+ vs. } \mathrm{Ag} / \mathrm{Ag}+)}=0.45$ $\mathrm{eV}$ ). It can be seen that polymers $\mathbf{P 1 - P 4}$ possess quasireversible $\mathrm{p}$-doping/dedoping (oxidation/rereduction) processes at positive potentials and reversible n-doping/dedoping (reduction/reoxidation) processes at negative potentials.

The onset oxidation and reduction potentials of polymers P1-P4 were in the ranges of 1.07-0.99 V and (-0.75)$(-0.82) \mathrm{V}$, respectively, from which the estimated HOMO and LUMO levels were found in the range of $(-5.34)-(-5.42) \mathrm{eV}$ and (-3.55) $-(-3.60) \mathrm{eV}$, respectively. The lower HOMO energy levels of the polymers were desirable for high open circuit voltages of PSCs, as the polymers were taken as donor materials. ${ }^{8}$ The noticeably higher oxidation potentials of P1-P4 can be explained by that the resulting conjugated copolymers were more electron deficient because of the nitrogen atoms in their planar $\pi$-conjugated systems. ${ }^{18(\mathrm{c}), 19(\mathrm{~b})}$ On the other hand, the LUMO energy level of the electron donor (polymer) has to be positioned above the LUMO energy level of the electron acceptor (PCBM) at least $0.3 \mathrm{eV}$, so the exciton binding energy of polymer could be overcome and result in efficient electron transfer from donor to acceptor. $^{3}$ The high reduction potentials of polymers P1-P4 represent high electron affinities to make these copolymers suitable donors to inject and transport electrons to PCBM acceptor in PSC devices. ${ }^{3(a), 20(b)}$ The differences between the band gap values directly measured by $\mathrm{CV}\left(E_{\mathrm{g}}^{\mathrm{ec}}\right.$ between 1.79 and $1.82 \mathrm{eV}$ ) and the optical band gap values obtained from UV-vis spectra ( $E_{\mathrm{g}}^{\text {opt }}$ between 1.93 and $1.99 \mathrm{eV}$ ) lied within an acceptable range of errors.

\section{PV Properties}

To investigate the potential applications of copolymers in PSC devices, BHJ solar cells were fabricated by using polymers P1-P4 as electron donors and fullerene [6,6]-phenyl$\mathrm{C}_{61}$-butyric acid methyl ester $\left(\mathrm{PC}_{61} \mathrm{BM}\right)$ as an electron acceptor with a device configuration of ITO/PEDOT:PSS(30 nm)/(P1-P4):PCBM(1:1 w/w $)(\sim 80 \mathrm{~nm}) / \mathrm{Ca}(30 \mathrm{~nm}) / \operatorname{Al}(100$ $\mathrm{nm}$ ). This weight ratio of polymer blends with PCBM (P1$\mathbf{P 4}: \mathrm{PCBM}=1: 1 \mathrm{w} / \mathrm{w}$ ) was found to have the optimum PCE value. Figure 4 shows the $J-V$ curves of all PSCs containing P1-P4 under the condition of AM 1.5 at $100 \mathrm{~mW} / \mathrm{cm}^{2}$, and the open circuit voltage $\left(V_{\text {oc }}\right)$, short circuit current density $\left(U_{\text {sc }}\right), F F$, and PCE values of the devices are summarized in Table 3. To have the great performance in PSC devices, DCB was chosen as the solvent to obtain the blended polymer active layers with good film qualities. The obtained PCE values of polymers P1-P4 were in the range of $0.36-0.57 \%$, where P3 and P4 possessed the highest PCE value $(0.57 \%)$. However, the similar alternating copolymer reported by $\mathrm{Li}$ et al., which comprised of a planar carbazole unit as an electron donor and a bithiazole unit as an electron acceptor 


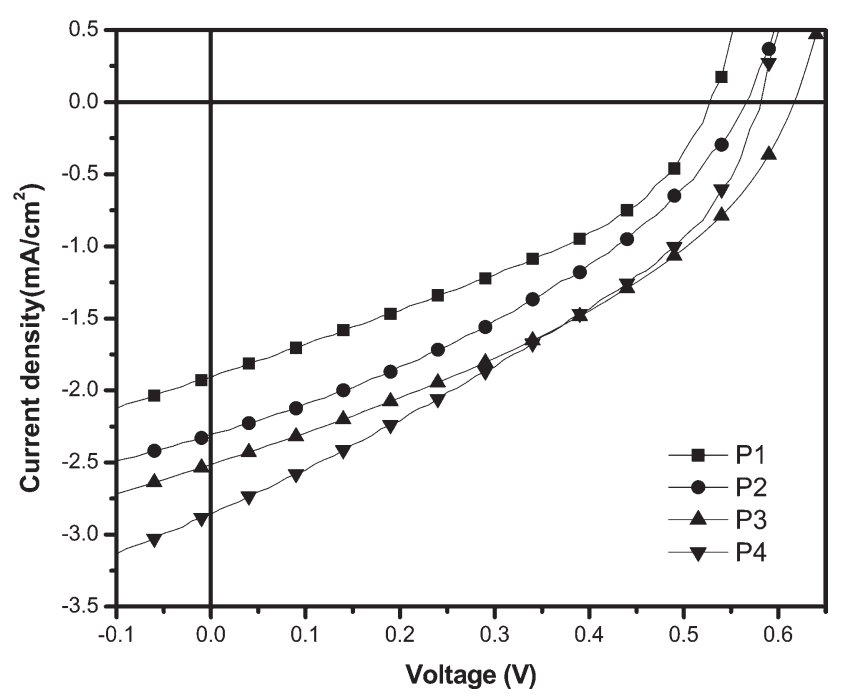

FIGURE 4 J-V characteristics of ITO/PEDOT:PSS/P1-P4:PC61BM $(1: 1 \mathrm{w} / \mathrm{w}) / \mathrm{Ca} / \mathrm{Al}$ under illumination of $\mathrm{AM} 1.5$ at $100 \mathrm{~mW} / \mathrm{cm}^{2}$.

sandwiched between thiophene units, only achieved a lower PCE value of $0.30 \%{ }^{10(e)}$

Although both PSC devices containing P3 and P4 possessed the highest PCE value (PCE $=0.57 \%$ ), P4 generated a higher $J_{\text {sc }}$ value, a higher absorption coefficient, and an efficient red shift in UV-vis spectrum compared with those of P3. Therefore, the PSC device containing P4 was chosen to be optimized in further PV studies. To acquire the advantage of a higher absorption coefficient of $\mathrm{PC}_{71} \mathrm{BM}^{27}$ than $\mathrm{PC}_{61} \mathrm{BM}$, the BHJ PSC devices with different weight ratios of $\mathbf{P 4}$ (as an electron donor) and $\mathrm{PC}_{71} \mathrm{BM}$ (as an electron acceptor) were fabricated, and their $J-V$ characteristics and PV properties are illustrated in Figure 5(a) and Table 4, respectively. The optimum PCE value of $1.01 \%$ was obtained in the PSC device having a weight ratio of $\mathbf{P 4}: \mathrm{PC}_{71} \mathrm{BM}=1: 1.5$ (with $V_{\mathrm{oc}}=0.60$ $\mathrm{V}, J_{\mathrm{sc}}=4.83 \mathrm{~mA} / \mathrm{cm}^{2}$, and $\left.\mathrm{FF}=35 \%\right)$. Using a lower weight ratio of PCBM in blended polymer $\mathbf{P 4}: \mathrm{PC}_{71} \mathrm{BM}(1: 1 \mathrm{w} / \mathrm{w})$ led to a reduction in the $J_{\mathrm{sc}}$ value, which could be attributed to the inefficient charge separation and electron transporting properties, resulting in the lower PCE value. ${ }^{28}$ However, loading larger weight ratios of PCBM in blended copolymers

TABLE 3 Photovoltaic Properties of Polymer Solar Cell (PSC) Devices with a Configuration of ITO/PEDOT:PSS/P1-P4:PC ${ }_{61} \mathrm{BM}(1: 1 \mathrm{w} / \mathrm{w}) / \mathrm{Ca} / \mathrm{Al}^{\mathrm{a}}$

\begin{tabular}{lllll}
\hline $\begin{array}{l}\text { Active Layer } \\
\text { (Polymer:PC }\end{array}$ B1 $\left.\mathrm{BM}=1: 1\right)$ & $\begin{array}{l}V_{\mathrm{oc}} \\
(\mathrm{V})\end{array}$ & $\begin{array}{l}J_{\mathrm{sc}} \\
\left(\mathrm{mA} / \mathrm{cm}^{2}\right)\end{array}$ & $\begin{array}{l}\mathrm{FF} \\
(\%)\end{array}$ & $\begin{array}{l}\text { PCE } \\
(\%)\end{array}$ \\
P1 & 0.53 & 1.93 & 35 & 0.36 \\
P2 & 0.56 & 2.31 & 36 & 0.46 \\
P3 & 0.62 & 2.52 & 37 & 0.57 \\
P4 & 0.58 & 2.87 & 34 & 0.57
\end{tabular}

a Measured under AM 1.5 irradiation, $100 \mathrm{~mW} / \mathrm{cm}^{2}$.

${ }^{b}$ Active layer of blended polymers with the weight ratio of P1$\mathbf{P} 4: \mathrm{PC}_{61} \mathrm{BM}=1: 1$.
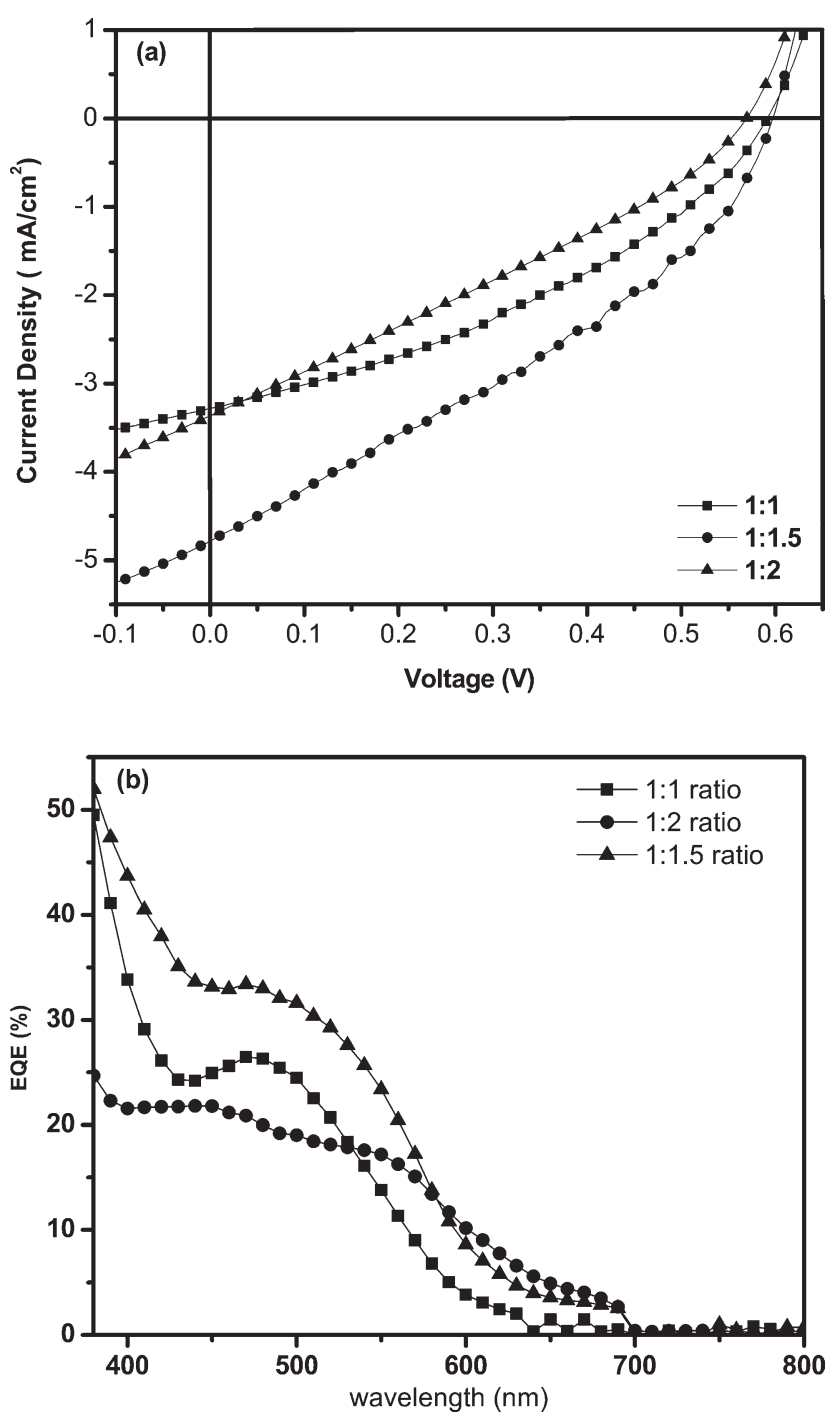

FIGURE 5 (a) $J-V$ characteristics of ITO/PEDOT:PSS/P4:PC ${ }_{71} \mathrm{BM} /$ $\mathrm{Ca} / \mathrm{Al}$ under illumination of $\mathrm{AM} 1.5$ at $100 \mathrm{~mW} / \mathrm{cm}^{2}$. (b) $\mathrm{EQE}$ curves of PSC devices based on polymer blends $P 4 / \mathrm{PC}_{71} \mathrm{BM}$ in various weight ratios.

TABLE 4 Photovoltaic Properties ${ }^{\text {a }}$ of Bulk-Heterojunction PSC Devices Containing Different Weight Ratios of Blended Polymers P4:PC ${ }_{71} \mathrm{BM}$ and Blend Film Roughness by AFM Measurements

$\begin{array}{llllll}\begin{array}{l}\text { Weight Ratios } \\ \text { of Blended }\end{array} & \begin{array}{l}V_{\mathrm{oc}} \\ \text { P4:PC }{ }_{71} \mathrm{BM}\end{array} & \begin{array}{l}J_{\mathrm{sc}} \\ (\mathrm{V})\end{array} & \begin{array}{l}\left.\mathrm{FF} / \mathrm{cm}^{2}\right) \\ (\%)\end{array} & \begin{array}{l}R_{\mathrm{rms}} \\ (\mathrm{nm})^{\mathrm{b}}\end{array} & \begin{array}{l}\text { PCE } \\ (\%)\end{array} \\ 1: 1 & 0.60 & 3.30 & 39 & 0.20 & 0.77 \\ 1: 1.5 & 0.60 & 4.83 & 35 & 0.17 & 1.01 \\ 1: 2 & 0.58 & 3.42 & 28 & 0.22 & 0.55\end{array}$

a Measured under AM 1.5 irradiation, $100 \mathrm{~mW} / \mathrm{cm}^{2}$.

${ }^{\mathrm{b}} R_{\mathrm{rms}}$ : root-mean-square values of roughnesses measured from AFM images. 

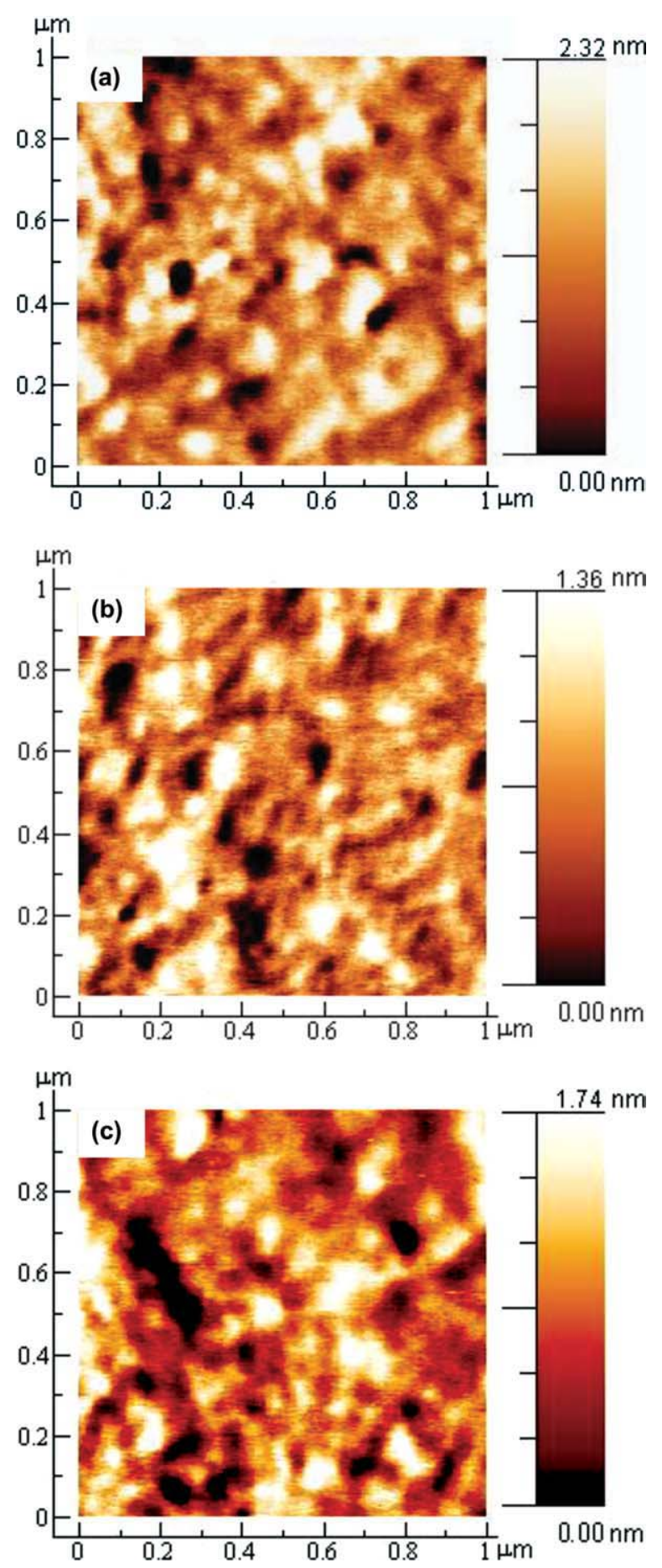

FIGURE 6 AFM images of blended polymer P4:PC71BM spin coated from DCB in the ratios of (a) 1:1 (w/w), (b) 1:1.5 (w/w), and (c) $1: 2(\mathrm{w} / \mathrm{w})$ with a size of $1 \times 1 \mu \mathrm{m}^{2}$.

P4:PC ${ }_{71} \mathrm{BM}(1: 2 \mathrm{w} / \mathrm{w})$ also reduced the $J_{\mathrm{sc}}$ and PCE values, which could be probably attributed to the increased aggregation of PCBM so as to influence the separation of charges. Hence, both $J_{\mathrm{sc}}$ and PCE values decreased with larger PCBM molar ratios of $1: 2(\mathrm{w} / \mathrm{w})$ because of the reasons described here. ${ }^{15(\mathrm{e})}$ To investigate the different efficiencies of the PSC devices, the EQEs for polymer $\mathbf{P 4}$ blended with $\mathrm{PC}_{71} \mathrm{BM}$ in various weight ratios were further investigated in Figure 5(b), where the PSC devices exhibited a very broad response range covering from 400 to $700 \mathrm{~nm}$ with the maximum EQE values of $27 \%, 34 \%$, and $22 \%$ for $\mathbf{P} 4: \mathrm{PC}_{71} \mathrm{BM}=1: 1,1: 1.5$, and $1: 2(\mathrm{w} / \mathrm{w})$, respectively. Therefore, the photocurrent generation in the PSC device with $\mathbf{P 4}: \mathrm{PC}_{71} \mathrm{BM}=1: 1.5(\mathrm{w} / \mathrm{w})$ is higher and leading to the highest PCE value because of more light harvest in the visible region.

Surface morphology of the active layer is also the key parameter for device performance in PSC devices. ${ }^{29}$ The AFM topographic images of the polymer blends of $\mathbf{P 4}: \mathrm{PC}_{71} \mathrm{BM}$ in various weight ratios $(1: 1,1: 1.5$, and $1: 2)$ are presented at Figure $6(\mathrm{a}-\mathrm{c})$ and their root-mean-square values of roughness $\left(R_{\text {rms }}\right)$ are presented in Table 4 . It is clearly seen that all the phase images possessed almost similar coarse surfaces, which were attributed to the domains of highly stacked polymer chains in P4. ${ }^{21(\mathrm{a})}$ The most coarse surface of $R_{\mathrm{rms}}=$ $0.22 \mathrm{~nm}$ in $\mathbf{P 4}: \mathrm{PC}_{71} \mathrm{BM}=1: 2(\mathrm{w} / \mathrm{w})$ indicated a large scale phase separation, which might decrease the diffusional escape probability for mobile charge carriers and thus to increase charge recombination. ${ }^{30,16(\mathrm{~d})}$ However, the decrease of $\mathrm{PC}_{71} \mathrm{BM}$ content in $\mathbf{P 4}: \mathrm{PC}_{71} \mathrm{BM}=1: 1(\mathrm{w} / \mathrm{w})$ reduced the $R_{\text {rms }}$ value to $0.20 \mathrm{~nm}$, which led to a similar $J_{\mathrm{sc}}$ value with that of $\mathbf{P 4}: \mathrm{PC}_{71} \mathrm{BM}=1: 2(\mathrm{w} / \mathrm{w})$. Compared with the other blending ratios of $\mathbf{P 4}: \mathrm{PC}_{71} \mathrm{BM}$, a smoothest surface with $R_{\mathrm{rms}}$ $=0.17 \mathrm{~nm}$ was obtained in $\mathbf{P 4}: \mathrm{PC}_{71} \mathrm{BM}=1: 1.5(\mathrm{w} / \mathrm{w})$, which enhanced the $J_{\mathrm{sc}}$ value and yielded the highest efficiency (PCE $=1.01 \%$ ) in PSCs. ${ }^{30}$

\section{CONCLUSIONS}

In conclusion, a series of conjugated main-chain copolymers consisting of 2,7-carbazole electron-donating unit and bithiazole electron-accepting unit were synthesized by $\operatorname{Pd}(0)$-catalyzed Stille coupling polymerization. Carbazole-based polymers exhibited broad absorption bands located in the UV and visible regions from 300 to $600 \mathrm{~nm}$ with optical band gaps of 1.93-1.99 eV. The HOMO and LUMO energy levels of the polymers can be finely tuned via the molecular engineering of donor/acceptor moieties and conjugated linkers inside the copolymers, which possessed relatively lower HOMO levels for PSC applications. The BHJ PV devices using polymers P1-P4 as electron donors and $\mathrm{PC}_{61} \mathrm{BM}$ as electron acceptors were fabricated, and the optimization of PSC devices with $\mathbf{P 4}: \mathrm{PC}_{71} \mathrm{BM}$ in different weight ratios were investigated. Finally, the PV device bearing an active layer of polymer blend P4:PC ${ }_{71} \mathrm{BM}(1: 1.5 \mathrm{w} / \mathrm{w})$ showed the best PCE value of $1.01 \%$, with a short circuit current density $\left(U_{\mathrm{sc}}\right)$ of $4.83 \mathrm{~mA} /$ $\mathrm{cm}^{2}$, a FF of $35 \%$, and $V_{\text {oc }}=0.60 \mathrm{~V}$ under $100 \mathrm{~mW} / \mathrm{cm}^{2}$ of AM 1.5 white-light illumination. AFM images reveled that there were a better mixing between polymers and $\mathrm{PC}_{71} \mathrm{BM}$ to generate a less scale phase separation. Although the PCE values of all PSC devices were not sufficiently high, the tunable optoelectronic properties could be achieved by the structural modifications of electron donor and acceptor units.

The authors thank to the National Center for High-performance Computing for computer time and facilities. The financial 
supports of this project provided by the National Science Council of Taiwan (ROC) through NSC 97-2113-M-009-006-MY2, National Chiao Tung University through 97W807, and Energy and Environmental Laboratories (charged by Dr. Chang-Chung Yang) in Industrial Technology Research Institute (ITRI) are acknowledged.

\section{REFERENCES AND NOTES}

1 (a) Roncali, J. Chem Rev 1997, 97, 173-205; (b) Yu, G.; Gao, J.; Hummelen, J. C.; Wudl, F.; Heeger, A. J. Science 1995, 270, 1789-1791; (c) Cheng, Y. J.; Yang, S. H.; Hsu, C. S. Chem Rev 2009, 109, 5868-5923; (d) Bundgaard, E.; Krebs, F. C. Sol Energy Mater Sol Cells 2007, 91, 954-985; (e) Shrotriya, V. Nat Photonics 2009, 3, 447-449.

2 (a) Velusami, M.; Huang, J.-H.; Hsu, Y.-C.; Chou, H.-H; Ho, K.C.; Wu, P.-L.; Chang, W.-H.; Lin, J. T.; Chu, C.-W. Organic Letters 2009, 4898-4901; (b) Huang, J. H.; Velusami, M.; Ho, K. C.; Lin, J.-T.; Chu, C.-W. J Mater Chem 2010, 20, 2820-2825; (c) Zhang J.; Yang Y.; He C.; He Y.; Zhao G.; Li Y. Macromolecules 2009, 42, 7619-7622; (d) Walker, B.; Tamayo, A. B.; Dang, X.-D.; Zalar, P.; Seo, J. H.; Gercia, A.; Tantiwiwat, M.; Nguyen, T.-Q. Adv Funct Mater 2009, 19, 3063-3069.

3 (a) Brabec, C. J.; Sariciftci, N. S.; Hummelen, J. C. Adv Funct Mater 2001, 11, 15-26; (b) Coakley, K. M.; McGehee, M. D. Chem Mater 2004, 16, 4533-4542; (c) G, Li.; V, Shrotriya.; Huang, J.; Yao, Y.; Moriarty, T.; Emery, K.; Yang, Y. Nat Mater 2005, 4, 864-868; (d) Günes, S.; Neugebauer, H.; Sariciftci, N. S. Chem Rev 2007, 107, 1324-1338; (e) Thompson, B. C.; Frechet, J. M. J. Angew Chem Int Ed 2008, 47, 58-77.

4 (a) Liang, Y.; Feng, D.; Wu, Y.; Tsai, S.-T.; Li, G.; Ray, C.; Yu, L. J Am Chem Soc 2009, 131, 7792-7799; (b) Chen, H.-Y.; Hou, J.; Zhang, S.; Liang, Y.; Yang, G.; Yang, Y.; Yu, L.; Wu, Y.; Li. G. Nat Photonics 2009, 3, 649-653; (c) Park, S. H.; Roy, A.; Beaupré, S.; Cho, S.; Coates, N.; Moon, J. S.; Moses, D.; Leclerc, M.; Lee, K.; Heeger, A. J. Nat Photonics 2009, 3, 297-303.

5 (a) Zho, Y.; Gendron, D.; Neagu-Plesu, R.; Leclerc, M. Macromolecules 2009, 42, 6361-6365; (b) Li, Y.; Zhu, Y. Adv Mater 2008, 20, 2952-2958.

6 (a) Huo, L.; Tan, Z. A.; Wang, X.; Zhou, Y.; Han, M.; Li, Y. J Polym Sci Part A: Polym Chem 2008, 46, 4038-4049; (b) Chen, C.-P.; Chan, S.-H.; Chao, T.-C.; Ting, C.; Ko, B.-T. J Am Chem Soc 2008, 130, 12828-12833.

7 Dennler, G.; Scharber, M.; Brabec, C. J. Adv Mater 2009, 21, 1323-1338.

8 Brédas, J.-L.; Beljonne, D.; Coropceanu, V.; Cornil, J. Chem. Rev. 2004, 104, 4971-5003.

9 (a) Petersen, M. H.; Hagemann, O.; Nielsen, K.T,; Jørgensen, M.; Krebs, F.C. Sol Energy Mater Sol Cells, 2007, 91, 996-1009; (b) Peng, Q.; Xu, J.; Zheng. J Polym Sci Part A: Polym Chem 2009, 47, 3399-3408; (c) Huo, L.; Tan, Z.; Wang, X.; Zhou, Yi.; Han, M.; Li, Y. J Polym Sci Part A: Polym Chem 2007, 46, 4038-4049.

10 (a) Blouin, N.; Michaud, A.; Leclerc, M. Adv Mater 2007, 19, 2295-2300; (b) Blouin, N.; Michaud, A.; Gendron, D.; Wakim, S.; Blair, E.; Neaguplesu, R.; Belletete, M.; Durocher, G.; Tao, Y.;
Leclerc, M. J Am Chem Soc 2008, 130, 732-742; (c) Zou, Y.; Gendron, D.; Aïch, R. B.; Najari, A.; Tao, Y.; Leclerc, M. Macromolecules 2009, 42, 2891-2894; (d) Qin, R. P.; Li, W. W.; Li, C. H.; Du, C.; Veit, C.; Schleiermacher, H. F.; Andersson, M.; Bo, Z. S.; Liu, Z. P.; Inganäs, O.; Wuerfel, U.; Zhang, F. L. J Am Chem Soc 2009, 131, 14612; (e) Zhang, M.; Fan, H.; Guo, X.; He, Y.; Zhang, Z.; Min, J.; Zhang, J.; Zhao, G.; Zhan, X.; Li, Y. Macromolecules 2010, 43, 5706-5712.

11 (a) Daun, C.; Cai, W.; Huang, F.; Zhang, J.; Wang, M.; Yang, T.; Zhong, C.; Gong, X.; Cao, Y. Macromolecules 2010, 43, 5262-5268; (b) Boudreault, P. T.; Michaud, A.; Leclerc, M. Macromol Rapid Commun 2007, 28, 2176-2179.

12 (a) Mühlbacher, D.; Scharber, M.; Morana, M.; Zhu, Z.; Waller, D.; Gaudiana, R.; Brabec, C. Adv Mater 2006, 18, 2884-2889; (b) Peet, J.; Kim, J. Y.; Coates, N. E.; Ma, W. L.; Moses, D.; Heeger, A. J.; Bazan, G. C. Nat Mater 2007, 6, 497-500; (c) Li, K. C.; Hsu, Y.-C.; Lin, J.-T.; Yang, C.-C.; Wei, K. W.; Lin, H.-C. J Polym Sci Part A: Polym Chem 2009, 47, 2073-2092.

13 (a) Zhou, E.; Nakamura, M.; Nishizawa, T.; Zhang, Y.; Wei, Q.; Tajima, K.; Yang, C.; Hashimoto, K. Macromolecules. 2008, 41, 8302-8305; (b) Zhou, E.; Wei. Q.; Yamakawa, S.; Zhang, Y.; Tajima, K.; Yang, C.; Hashimoto, K. Macromolecules 2010, 21, 821-826; (c) Yue, W.; Zhao, Y.; Shao, S.; Tian, H.; Xie, Z.; Geng, Y.; Wang, F. J Mater Chem 2009, 19, 2199-2206.

14 (a) Liao, L.; Dai, L.; Smith, A.; Durstock, M.; Lu, J.; Ding, J.; Tao, Y. Macromolecules 2007, 40, 9406-9412; (b) Hou, J.; Chen, H.-Y.; Zhang, S.; Li, G.; Yang, Y. J Am Chem Soc 2008, 130, 16144-16145; (c) Huo, L.; Chen, H.-Y.; Hou, J.; Chen. T. L.; Yang, Y. Chem Commun 2009, 5570-5572.

15 (a) Wang, E.; Wang, M.; Wang, L.; Duan, C.; Zhang, J.; Cai, W.; He, C.; Wu, H.; Cao, Y. Macromolecules 2009, 42, 4410-4415; (b) Chen, M. H.; Hou, J.; Hong, Z.; Yang, G.; Sista, S.; Chen, L. M.; Yang, Y. Adv Mater 2009, 21, 4238-4242; (c) Gadisa, A.; Mammo, W.; Andersson, L. M.; Admassive, S.; Zhang, F.; Andersson, M. R.; Inganäs, O. Adv Funct Mater 2007, 17, 3836-3842; (d) Li, Y.; Li, H.; Xu, B.; Li, Z.; Chen, F.; Feng, D.; Zhang. J.; Tian, W. Polymer 2010, 51, 1786-1795.

16 (a) Tang, W.; Kietzke, T.; Vemulamada P.; Chen, Z.-K. Polym Sci Part A: Polym Chem 2007, 4, 5266-5276; (b) Huang, J. H.; Li, K. C.; Wei, H. Y.; Chen, P. Y.; Lin, L.Y.; Kekuda, D.; Lin, H. C.; Ho, K. C.; Chu, C. W. Organic Electronics 2009, 10, 1109-1115; (c) Li, K.-C.; Hsu, Y.-C.; Lin, J.-T.; Yang, C.-C.; Wei, K. W.; Lin, H.-C. J Polym Sci Part A: Polym Chem 2008, 46, 4285-4304; (d) Huang, J. H.; Ho, Z. Y.; Kekuda, D.; Chang, Y.; Chu, C. W.; Ho, K. C. Nanotechnology 2009, 20, 025202.

17 (a) Osaka, I.; Sauvé, G.; Zhang, R.; Kowalewski, T.; McCullough, R. D. Adv Mater 2007, 19, 4160-4165; (b) Mamada, M.; Nishida, J.; Kumaki, D.; Tokito, S. Chem Mater 2007, 19, 5404-5409.

18 (a) Yasuda, T.; Sakai, Y.; Aramaki, S.; Yamamoto, T. Chem Mater 2005, 17, 6060-6068; (b) Yamamoto, T.; Suganuma, H.; Maruyama, T.; Inoue, T.; Muramatsu, Y.; Arai, M.; Komarudin, D.; Ooba, N.; Tomaru, S.; Sasaki, S.; Kubota, K. Chem Mater 1997, 9, 1217-1225.

19 (a) Ahmed, E.; Kim, F. S.; Xin, H.; Jenekhe, S. A. Macromolecules 2009, 42, 8615-8618; (b) Curtis, M. D.; Nanos, J. I.; 
Moon, H.; Jhang, W, S. J Am Chem Soc 2007, 129, 15072-15084.

20 (a) Wong, W.-Y.; Wang, X.-Z.; He, Z.; Chen, K.-K.; Djurišić, A. B.; Cheung, K.-Y.; Yip, C.-T.; Ng, A. M.-C.; Xi, Y. Y.; Mak, C. S. K.; Chan, W.-K. J Am Chem Soc 2007, 129, 14372-14380; (b) Lee, J.; Jung, B. J.; Lee, S. K.; Lee, J. I.; Cho, H. J.; Shim, H. K. J Polym Sci Part A: Polym Chem 2005, 43, 1845-1857.

21 (a) Li, K. C.; Huang, J. H.; Hsu, Y. C.; Huang, P.J.; Chu, C. W.; Lin, J. T.; Ho, K. C. Lin, H. C. Macromolecules 2009, 42, 3681-3693; (b) Huang, J. H.; Li, K. C.; Kekuda, D.; Padhy, H. H.; Lin, H. C.; Ho. K. C.; Chu, C. W. J Mater Chem 2010, 20, 3295-3300.

22 Wei, Y.; Yang, Y.; Yeh, J.-M. Chem Mater 1996, 8, 2659-2666.

23 (a) Zhag, S.; Guo, Y.; Fan, H.; Liu, Y.; Chen, H.-Y.; Yang, G.; Zhan, X.; Liu, Y.; Li, Y.; Yang, Y. J Polym Sci Part A: Polym Chem 2009, 47, 5498-5508.

24 (a) Chan, S.-H.; Chen, C.-P.; Chao, T.-C.; Ting, C.; Lin, C.-S.; Ko, B.-T. Macromolecules 2008, 41, 5519-5526; (b) Jung, I. H.; Yu, J.; Jeong, E.; Kwon, S.; Kong, H.; Lee, K.; Woo, H.Y.; Shim, H.K. Chem Eur J 2010, 16, 3743-3752.
25 (a) Xaio, S.; Stuart, A. C.; Liu, S.; You, W. ACS Appl Mater Intrfaces 2007, 7, 1613-1621; (b) Li, Y.; Li, Z.; Wang, C.; Li, H.; Lu, H.; Xu, B.; Tian, W. Polym Sci Part A: Polym Chem 2010, 48, 2765-2776; (c) Wong, W.-Y. Macromol Chem Phys 2008, 209, 14-24.

26 (a) Liang, T. C.; Chiang, I. H.; Yang, P. J.; Kekuda, D.; Chu, C. W.; Lin, H. C. J Polym Sci Part A: Polym Chem 2009, 47, 5998-6013.

27 (a) Liang, Y.; Wu, Y.; Feng, D.; Tsai, S.-T.; Son, H.-J.; Li, G.; Yu, L. J Am Chem Soc 2009, 131, 56-57; (b) Jung, I. H.; Kim, H.; Park, M.-J.; Kim, B.; Park, J.-H.; Jeong, E.; Woo, H. Y.; Yoo, S.; Shim, H.-K. J Polym Sci Part A: Polym Chem 2010, 48, 1423-1432.

28 (a) Baek, N. S.; Hau, S. K.; Yip, H. L.; Acton, O.; Chen, K. S.; Jen, A. K. Y. Chem Mater 2008, 20, 5734-5736.

29 Zhou, Y. H.; Wang, Y. N.; Wu, W. C.; Wang, H.; Han, L.; Tian, W. J.; Bassler, H. Sol Energy Mater Sol Cells 2007, 91, 1842-1848; (b) Liu, J.; Shi, Y. J.; Yang, Y. Adv Funct Mater 2001, 11, 420-424.

30 Li, Y.; Xue, L.; Li, H.; Xu, B.; Wen, S.; Tian, W. Macromolecules $2009,42,4491-4499$. 